documents the deep penetration of humanistic philology into the mind of a major church figure usually seen as a Thomist scholastic. This book is a very welcome addition to our knowledge of religious scholarship in the Renaissance.

PAUL F. GRENDLER

University of Toronto Emeritus

\title{
O'Meara, John.
}

Remembering Shakespeare: The Scope of His Achievement from Hamlet through The Tempest.

Toronto: Guernica, 2016. Pp. vii, 205. ISBN 978-1-77183-227-4 (paperback) $\$ 20$.

John O'Meara's Remembering Shakespeare sets out a distinct path on which we live through Shakespeare living through Hamlet as tragedy-the turning point in Shakespeare's career-and subsequent tragedies, and then through a romance like The Tempest. O'Meara seeks to explore what, for Shakespeare, is "the point of tragedy for himself" (1). By this, O'Meara means that the issues go beyond the will of the Ghost in Hamlet or of Shakespeare, even, and that "both the Ghost and Shakespeare would have had to submit to a universe that requires much more of us than we seem ever ready to admit” (1). O’Meara elaborates on this thesis by quoting Hamlet's words to Horatio that in earth and heaven there are more things than his philosophy can dream of, as if that thought applies to Shakespeare (1). Like Hamlet, Shakespeare had to learn the lesson of not protesting and expressing words of outrage but of renouncing so much "to satisfy the will of the universe that, for our instruction, had taken him over" (1). The clause, "for our instruction," is a little jarring and unexpected. It is as if Shakespeare had to accept the will of the universe for the sake of his audience. In a sense, he was trying to redeem us; his tragedy, for O'Meara, is that since his time we have not been instructed by his pains (1).

O'Meara thinks we need to open our understanding, especially of Shakespeare's romances, and this failure to comprehend comes from our inability to live through tragedy (1-2). According to O'Meara, Shakespeare deliberately used Hamlet, Othello, Lear, and Macbeth to give him such an experience (2). What O'Meara has in mind is not catharsis but "fully passing through tragedy 
without holding anything back or holding on to this or that consolation" (2). Shakespeare was able to achieve this and represent extraordinary states of being in the romances (2-3). This drama or "form of initiation theater," according to O'Meara, takes us further to those states of being; this theatre "literally enacts the processes of redemption and of resurrection" (3). O'Meara explains his central point: "At the heart of this initiation theater is the understanding that not only is human tragedy not to be forgotten, the whole history of human tragedy as such is to be paradigmatically revived" (3). O'Meara relates Christopher Marlowe and Martin Luther to Shakespeare (4-5, 9-11, 14-15, 16-22). For instance, Marlowe's Doctor Faustus represents "a hopelessly overwhelmed humanity" and in Hamlet Shakespeare gathers up the best of himself and then "plunges into a Luther-like confrontation with the very worst of human nature" (23). O'Meara sees Prospero and Miranda in Tempest as braving this destructive force (32).

O'Meara has many suggestive ideas; in the scope of my response, I can mention only a few. By the end of Hamlet, the prince "has undergone an experience of providential re-direction of his destiny that roughly suggests the Lutheran experience of faith" (35). Death, perhaps the ultimate negation, is also a concern for O'Meara in his interpretation of Hamlet: “The perception of a complex operation of meaning is required to show how and in what sense the play's extended meditation on death serves in the last part of the play as a formal acknowledgment of human limitation before the mystery of visionary destiny" (69). There is a religious, allegorical, mystical, and philosophical aspect to O'Meara's book. In the tragedies, Shakespeare goes through a "great process of negation" and then he provides "a miraculous recrudescence of otherworldly, salvific, and romantic terms" (87). In this context, O'Meara speaks about Rudolf Steiner and a hidden human wisdom for understanding (88; see also 122-25, $135,148,160-65)$. O'Meara has some very specific views when discussing the tragedies and the romances, whether Hamlet, Othello, Tempest, or other plays, calling on Steiner, the Rosicrucians, and others adept in arcane knowledge (see, for instance, 160, 176). In the expanding world of Shakespeare's last plays, O’Meara sees an "Imaginative allegory" (178). To give a sense of the symbology and the construction of a hermetic framework, I quote the last sentence of the body of O'Meara's work: “And it is in this respect that Shakespeare's account of the Higher Ego in his last plays, as illuminated by Steiner's science of the spirit, takes the further lead into a future inheritance of which we have had but the first 
intimations thus far" (178). O'Meara calls on other interpretations and theories and imports them to support his idea that Shakespeare himself did not know how far he had gone into the pain of tragedy and the hope of romance, and that we are even less aware, subject to hints in the traces of evidence O'Meara has presented in his book.

This is not a usual volume in Shakespeare scholarship, but whether the reader agrees or not with O'Meara's argument or the details or readings of Shakespeare's plays, he or she will find something provocative in this book. O'Meara's work may serve as a catalyst. It does seem true that Shakespeare is inexhaustible in cultures around the globe-and not simply in England or the English-speaking countries, or among playgoers, readers, or scholars in the spheres of the theatre, drama, or literature. Shakespeare is suggestive across disciplinary and cultural boundaries, within and without universities. O'Meara's book is a challenge in many ways.

JONATHAN LOCKE HART

Shanghai Jiao Tong University

\section{Piéjus, Anne.}

Musique, censure et création. G. G. Ancina et le Tempio Armonico (1599). Biblioteca della Rivista di Storia e Letteratura Religiosa - Studi 33. Florence : Leo S. Olschki Editore, 2017. xxi, 470 p. +13 fig. et 12 exemples musicaux. ISBN 978-88-222-6492-3 (broché) $54 €$.

L'œuvre de Giovanni Giovenale Ancina a jusqu'à maintenant surtout attiré l'attention de chercheurs de langue italienne. Anne Piéjus nous offre ici la première étude d'ampleur de son œuvre en langue française. Si l'on considère qu'Ancina est le créateur de la plus grande collection de musique spirituelle du $\mathrm{XVI}^{\mathrm{e}}$ siècle, cette contribution est dès le départ inestimable. Il ne faut toutefois pas s'attendre à une étude de sources présentant une description physique et codicologique de l'œuvre examinée. L'auteure nous avertit dès le départ que l'examen du travail d'Ancina touche une série d'aspects d'histoire culturelle : l'histoire de la dévotion, de la lecture et de l'écriture, l'histoire du livre, et l'histoire de la musique et de son interprétation. Tous ces aspects convergent cependant en une étude qui s'intéresse d'abord à la censure de la poésie et 